\title{
Hubungan derajat dehidrasi dengan kadar hematokrit pada anak penderita diare di RSUP Prof. Dr. R. D. Kandou Manado
}

\author{
${ }^{1}$ Angely C. Rumayar \\ ${ }^{2}$ Jeanette I. Ch. Manoppo \\ ${ }^{3}$ Max F. J. Mantik
}

\author{
${ }^{1}$ Kandidat Skripsi Fakultas Kedokteran Universitas Sam Ratulangi Manado \\ ${ }^{2}$ Bagian Ilmu Kesehatan Anak Fakultas Kedokteran Universitas Sam Ratulangi Manado \\ RSUP Prof. Dr. R. D. Kandou Manado \\ Email: rumayarangely@yahoo.com
}

\begin{abstract}
The most severe threat that can inflicted by diarrhea is dehydration. In dehydration patients, hematocrit levels can increase. This study was aimed to find out the relationship between degree of dehydration and hematocrit level among diarrhea children at Prof. Dr. R. D. Kandou Manado hospital.This was an observational analytical study. Data were obtained from the medical record of pediatric patients retrospectively and were analyzed with the chi square test. The results showed that there were 40 pediatric patients with diarrhea. Most were females $(57.5 \%)$, and the average age was 8.5 years. Increased hematocrit level in diarrhea cases without dehydration was more dominant than in diarrhea cases with dehydration. The chi square test showed a $\mathrm{p}$ value of 0.949. Conclusion: There was no significant relationship between degree of dehydration and hematocrit level.
\end{abstract}

Keywords: diarrhea, children, degree of dehydration, hematocrit level

\begin{abstract}
Abstrak: Ancaman paling parah yang ditimbulkan oleh diare ialah dehidrasi. Dalam keadaan dehidrasi kadar hematokrit penderita dapat meningkat. Penelitian ini bertujuan untuk mengetahui hubungan derajat dehidrasi dengan kadar hematokrit pada anak penderita diare di RSUP Prof. Dr. R. D. Kandou Manado. Jenis penelitian ialah analitik observasional dengan pendekatan retrospektif. Data diperoleh dari rekam medik pasien anak di RSUP Prof. Dr. R. D. Kandou Manado dan dianalisis dengan uji chi square. Hasil penelitian mendapatkan 40 pasien anak dengan diare, terbanyak pada perempuan $(57,5 \%)$, usia ratarata 8,5 tahun, Peningkatan kadar hematokrit pada kasus diare tanpa dehidrasi lebih banyak dibandingkan kasus diare dengan dehidrasi. Hasil uji chi square menunjukkan nilai $\mathrm{p}=$ 0,494. Simpulan: Tidak terdapat hubungan bermakna antara derajat dehidrasi dengan kadar hematokrit.
\end{abstract}

Kata kunci: diare, anak, derajat dehidrasi, kadar hematokrit

Penyakit diare adalah suatu penyakit yang ditandai dengan perubahan bentuk dan konsistensi tinja yang lembek sampai cair dan bertambahnya frekuensi buang air besar lebih dari biasa, yaitu 3 kali atau lebih dalam sehari yang mungkin disertai muntah atau tinja yang berdarah. ${ }^{1}$

Prevalensi diare tersebar di semua kelompok usia dengan prevalensi tertinggi terdeteksi pada anak (1-4 tahun) yaitu $16,7 \%$ dan pada anak usia sekolah (5-14 tahun) didapatkan 9\%. ${ }^{2}$ Ancaman paling parah yang ditimbulkan oleh diare ialah dehidrasi. ${ }^{3}$ Evaluasi klinis pada penderita diare umumnya difokuskan pada penilaian keparahan dehidrasi serta identifikasi penyebab berdasarkan riwayat dan temuan klinis. ${ }^{4}$ Pemeriksaan darah rutin diperlukan 
pada keadaan tertentu misalnya penyebab dasarnya tidak diketahui ada sebab-sebab lain selain diare, atau penderita dengan dehidrasi berat. ${ }^{5}$ Kadar hematokrit berbedaberbeda tergantung dengan usia.

Dalam keadaan dehidrasi atau syok kadar hematokrit penderita dapat meningkat. ${ }^{5}$ Penelitian ini bertujuan untuk mengetahui hubungan derajat dehidrasi dengan kadar hematokrit pada anak penderita diare di RSUP Prof. Dr. R. D. Kandou Manado.

\section{METODE PENELITIAN}

Jenis penelitian ialah retrospektif dan analitik observasional dengan menggunakan data rekam medik penderita anak dengan diare dengan atau tanpa dehidrasi periode tahun 2013-2016. Penelitian dilakukan di Bagian Anak RSUP Prof. Dr. R. D Kandou Manado pada bulan Agustus - November 2016.

Kriteria inklusi rekam medik pasien anak berusia 5-12 tahun, pemeriksaan darah lengkap penderita diare dengan dehidrasi (ringan, sedang, atau berat) atau tanpa dehidrasi saat masuk rumah sakit di Bagian Anak RSUP Prof. Dr. R. D. Kandou Manado sedangkan kriteria eksklusi ialah pasien anak dengan komplikasi, gizi buruk, anemia, menderita penyakit jantung dan atau paru-paru, serta rekam medik yang tidak lengkap. Pengolahan data dilakukan dengan uji chi square untuk melihat ada tidaknya hubungan antara derajat dehidrasi dengan kadar hematokrit.

\section{HASIL PENELITIAN}

Hasil penelitian mendapatkan penderita anak diare dan menurut jenis kelamin, yang terbanyak ialah anak perempuan $(57,5 \%)$. Sampel diambil pada anak usia sekolah 5-12 tahun, dengan hasil kelompok usia terbanyak didapatkan pada kelompok usia 58 tahun, dengan rerata usia 7,91 tahun (Tabel 1).

Status gizi pada pasien anak dengan diare didapati paling banyak dengan status gizi baik sebanyak 60\% (Tabel 2).

Pekerjaan kedua orang tua didapatkan pekerjaan ayah terbanyak sebagai pegawai swasta dan pekerjaan ibu terbanyak sebagai IRT (Tabel 3).

Tabel 1. Karakteristik sampel anak yang menderita diare

\begin{tabular}{lc}
\hline Klasifikasi sampel & $\mathrm{n}(\%)$ \\
\hline Jenis kelamin & \\
Laki-laki & $17(42,5 \%)$ \\
Perempuan & $23(57,5 \%)$ \\
Usia & \\
5 - 8 Tahun & $26(65 \%)$ \\
9 - 12 Tahun & $14(35 \%)$ \\
Total & $40(100 \%)$ \\
\hline
\end{tabular}

Tabel 2. Distribusi berdasarkan status gizi

\begin{tabular}{lc}
\hline \multicolumn{1}{c}{ Status nutrisi } & $\mathrm{n}(\%)$ \\
\hline Gizi kurang & $11(27,5 \%)$ \\
Gizi baik & $24(60 \%)$ \\
Gizi lebih & $1(2,5 \%)$ \\
Obesitas & $4(10 \%)$ \\
Total & $40(100 \%)$ \\
\hline
\end{tabular}

Tabel 3. Distribusi berdasarkan pekerjaan orang tua

\begin{tabular}{lcc}
\hline \multicolumn{1}{c}{ Pekerjaan } & $\begin{array}{c}\text { Ayah } \\
\mathrm{n}(\%)\end{array}$ & $\begin{array}{c}\text { Ibu } \\
\mathrm{n}(\%)\end{array}$ \\
\hline Pegawai swasta & $12(30 \%)$ & $10(25 \%)$ \\
Wiraswasta & $6(15 \%)$ & $2(5 \%)$ \\
PNS & $7(17.5 \%)$ & $7(17.5 \%)$ \\
Petani & $4(10 \%)$ & $1(2.5 \%)$ \\
IRT & - & $18(45 \%)$ \\
Tidak bekerja & $2(5 \%)$ & - \\
Lain-lain & $9(22.5 \%)$ & $2(5 \%)$ \\
Total & $40(100 \%)$ & $40(100 \%)$ \\
\hline
\end{tabular}

Pada hasil penelitian ini kejadian diare dengan status dehidrasi didapatkan diare tanpa dehidrasi lebih banyak dibandingkan diare dengan dehidrasi ringan-sedang, tidak didapatkan diare dengan dehidrasi berat (Tabel 4). Hasil pemeriksaan kadar hematokrit mendapatkan banyak anak diare dengan peningkatan kadar hematokrit (Tabel 5). Hasil uji a Chi Square untuk mencari hubungan derajat dehidrasi dengan kadar hematokrit pada anak penderita diare mendapatkan nilai $\mathrm{p}=0,494$ (Tabel 6), yang menunjukkan tidak terdapat hubungan bermakna antara derajat dehidrasi dengan kadar hematokrit. 
Tabel 4. Distribusi berdasarkan status dehidrasi

\begin{tabular}{lc}
\hline \multicolumn{1}{c}{ Status dehidrasi } & $\mathrm{n}(\%)$ \\
\hline Diare tanpa dehidrasi & $28(70 \%)$ \\
Diare dengan dehidrasi & $12(30 \%)$ \\
ringan-sedang & 0 \\
$\begin{array}{l}\text { Diare dengan dehidrasi } \\
\text { berat }\end{array}$ & \\
Total & $40(100 \%)$ \\
\hline
\end{tabular}

Tabel 5. Distribusi berdasarkan kadar hematokrit

\begin{tabular}{lc}
\hline \multicolumn{1}{c}{ Hematokrit } & $\mathrm{n}(\%)$ \\
\hline Di bawah normal & $3(7,5 \%)$ \\
Normal & $16(40 \%)$ \\
Di atas normal & $21(52,5 \%)$ \\
Total & $40(100 \%)$ \\
\hline
\end{tabular}

Tabel 6. Hubungan derajat dehidrasi dengan kadar hematokrit

\begin{tabular}{llcccl}
\hline \multirow{2}{*}{ Derajat Dehidrasi } & \multicolumn{3}{c}{ Kadar Hematokrit } & & \\
\cline { 2 - 5 } & $\begin{array}{c}\text { Di bawah } \\
\text { Normal } \\
\mathrm{n}(\%)\end{array}$ & $\begin{array}{c}\text { Normal } \\
\mathrm{n}(\%)\end{array}$ & $\begin{array}{c}\text { Di atas } \\
\text { Normal } \\
\mathrm{n}(\%)\end{array}$ & $\begin{array}{c}\text { Total } \\
\mathrm{n}(\%)\end{array}$ & $\mathrm{p}$ Value \\
\hline - $\begin{array}{l}\text { Diare Akut tanpa } \\
\begin{array}{l}\text { Dehidrasi } \\
\text { Diare Akut dengan }\end{array}\end{array}$ & $3(10.7 \%)$ & 11 & $14(50 \%)$ & $\begin{array}{c}28 \\
(100 \%)\end{array}$ & \\
$\begin{array}{l}\text { Dehidrasi Ringan- } \\
\text { Sedang }\end{array}$ & - & $5(41.7 \%)$ & $7(58.3 \%)$ & 12 & $\mathrm{p}=0.494$ \\
\hline
\end{tabular}

\section{BAHASAN}

Penelitian ini dilakukan pada anakanak berusia 5-12 tahun yang datang ke Bagian Anak di RSUP Prof. Dr. R. D. Kanodu Manado. Penelitian ini dilakukan sejak bulan Agustus 2016 hingga November 2016. Empat puluh sampel yang didapat sesuai dengan kriteria inklusi pada periode waktu tahun 2013 hingga 2016.

Dari 40 sampel anak penderita diare yang sesuai dengan kriteria inklusi didapatkan 17 anak laki-laki dan 23 anak perempuan. Hal ini serupa dengan penelitian Sulaiman ${ }^{6}$ yang mendapatkan penderita perempuan $(51,9 \%)$ lebih tinggi dibandingkan dengan penderita laki-laki $(48,1 \%)$. Penelitian Palupi ${ }^{7}$ mendapatkan hasil yang berbeda yaitu pasien laki-laki lebih banyak daripada perempuan dengan perbandingan 5:1. Pada kasus tertentu jenis kelamin memengaruhi terjadinya suatu penyakit akan tetapi dalam hal diare, jenis kelamin tidak memberikan perbandingan yang jauh berbeda yang menunjukkan jenis kelamin tidak memengaruhi kejadian diare. $^{6}$

Pada penelitian ini didapatkan usia rata-rata 7,91 tahun (nilai median 8,24) dengan kejadian tertinggi pada anak diare kelompok usia 5-9 tahun sebanyak 65\% (Tabel 1). Angka kejadian diare usia sekolah hasil dari Riskesdas tahun 2013 mendapatkan prevalensi anak usia 5-14 tahun $4,1 \%{ }^{8}$ Pada penelitian Sulaiman ${ }^{6}$ didapatkan $5,44 \%$ pasien anak berusia 5 $<11$ tahun.

Pada Tabel 2 dapat dilihat bahwa status gizi baik pada 24 anak dan status gizi kurang 11 anak. Penelitian ini serupa dengan penelitian Primayani $^{9}$ yang mendapatkan hasil dengan gizi baik lebih tinggi daripada gizi kurang. Kurang gizi atau gizi buruk merupakan salah satu faktor risiko terbesar pada kejadian diare. Hasil penelitian Patanduk ${ }^{10}$ menunjukkan bahwa terdapat hubungan antara status gizi dengan kejadian diare di sekolah dasar Kecamatan Lindu $(\mathrm{p}=0,002)$.

Pekerjaan orang tua berubungan erat dengan status sosial ekonomi, sedangkan berbagai jenis penyakit yang timbul dalam keluarga sering berkaitan dengan jenis pekerjaan yang memengaruhi pendapatan keluarga. ${ }^{11}$ Pada penelitian ini didapatkan pekerjaan orang tua terbanyak sebagai pegawai swasta $30 \%$ untuk pekerjaan ayah 
dan sebagai IRT $45 \%$ untuk pekerjaan ibu anak penderita (Tabel 3).

Hasil penelitian pada kejadian diare tanpa dehidrasi lebih tinggi (70\%) dibandingkan dengan dehidrasi ringansedang $(30 \%)$ dan tidak didapatkan anak diare dengan dehidrasi berat (Tabel 4). Pada penelitian Rottie ${ }^{11}$ didapatkan hasil yang sama yaitu penderita diare akut tanpa dehidrasi lebih tinggi sedikit dibandingkan dehidrasi ringan-sedang, Kejadian diare dengan dehidrasi pada anak sekolah juga mulai menunjukkan hasil yang baik; hal ini menunjukkan pengetahuan orang tua mengenai hal diare dengan dehidrasi sudah lebih luas.

Pada Tabel 5 didapatkan kadar hematokrit di atas normal lebih banyak dibandingkan kadar hematokrit normal. Pada keadaan ini didapatkan hasil yang berbeda dengan penelitian Rottie ${ }^{11}$ yaitu kadar hematokrit di bawah normal 74,27\% dan di atas normal 11,23\%. Peningkatan nilai hematokrit dapat terjadi pada eritrositosis, dehidrasi, kerusakan paru-paru kronik, polisitemia, dan syok, juga pada orang-orang yang tinggal di tempat tinggi. Penurunan nilai hematokrit dapat disebabkan indikator anemia, leukemia, atau kehilangan banyak darah. ${ }^{12,13}$

Hubungan derajat dehidrasi dengan kadar hematokrit dilakukan dengan uji Chi Square $\quad(\mathrm{p}=0,449) \quad$ sehingga dapat disimpulkan tidak terdapat hubungan yang bermakna antara dejarat dehidrasi dengan kadar hematokrit (Tabel 6). Masih sedikit penelitian yang membahas secara langsung tentang derajat dehidrasi dengan kadar hematokrit. Penelitian oleh Rottie ${ }^{11}$ membandingkan kadar hematokrit dan diare akut dengan dehidrasi berat dan mendapat-kan keadaan yang sama bahwa kadar hematokrit normal lebih tinggi disbanding-kan kadar hematokrit diatas normal. Hal ini menunjukkan bahwa kadar hematokrit yang meningkat tidak selalu terjadi pada keadaan diare akut dengan dehidrasi berat. ${ }^{13}$ Hal ini mungkin berbeda dengan acuan pustaka yaitu nilai hematokrit dapat meningkat karena dehidrasi namun setelah rehidrasi yang adekuat maka akan kembali normal. ${ }^{11}$

\section{SIMPULAN}

Berdasarkan hasil penelitian yang dilakukan di RSUP Prof. R. D. Kandou Manado pada anak penderita diare dapat disimpulkan tidak terdpat hubungan bermakna antara derajat dehidrasi dengan kadar hematokrit.

\section{DAFTAR PUSTAKA}

1. World Health Organization. Diarrhoea. [cited 2016 Aug 25]. Available from: http://www.who.int/topics/diarrhoea/en

2. Anggraeni ND, Sibuea F. Situasi diare di Indonesia. In: Muliadi A, Manullang EV, Khairani, Widiantini W, Mulyanto NJ, editors. Buletin Jendela Data dan Informasi Kesehatan. 2011;2:1-8.

3. World Health Organization Media Centre. Diarrhoeal Disease. 2013 April [cited 2016 Sep 10]. Available from: http://www.who.int/mediacentre/factsh eets/fs330/en/\#

4. Pringle K, Shah SP, Umulisa I, Munyaneza RBM, Dushimiyimana JM, Stegmann K, et al. Comparing the accuracy of the three popular clinical dehydration scales in children with diarrhea. International Journal of Emergency Medicine. 2011;4(58):1-6.

5. World Health Organization. Variations in heamoglobin and haematocrit levels. Iron deficiency anaemia: assessment, prevention, and control a guide for programme managers. 2001; p. 97-101.

6. Sulaiman Y. Profil diare di ruang rawat inap anak. Sari Pediatri. 2011;13:265-70.

7. Palupi A, Hadi H, Soenarto SS. Status gizi dan hubungannya dengan kejadian diare pada anak diare akut di ruang rawat inap RSUP Dr. Sardjito Yogyakarta: Jurnal Gizi Klinik Indonesia. 2009;6:1-7

8. Riset kesehatan dasar 2013. Penyakit yang ditularkan melalui makanan, air, dan lainnya. Indonesia. 2013. p. 71-4

9. Primayani D. Status gizi pada pasien diare akut di ruang rawat inap anak RSUD Soe, Kabupaten Timur Tengah Selatan, NTT. Sari Pediatri. 2009;11:90-3.

10. Patanduk LD. Hubungan status gizi dengan tingkat kejadian diare pada anak usia 
sekolah dasar di Kecamatan Lindu wilayah resiko schistosomiasis tahun ajaran 2014/2015. Fakultas Kedokteran dan Ilmu Kesehatan Palu: Universitas Tadulako, 2015. Available from: lib.fkik.untad.ac.id.

11. Rottie YS, Mantik MFJ, Runtunuwu AL. Profil hematologi pada penderita diare akut yang dirawat di Bagian Ilmu Kesehatan Anak RSUP Prof. Dr. R. D. Kandou Manado periode November 2010-November 2011. eCl.
2015;3:838-44.

12. Indrawaty $S$, Sosialine $E$, Umar F, Pahlemy H, Andrajati R, Rianti A, et al. Interpretasi data laboratorium. Pedoman interpretasi data klinik. Jakarta: Kementrian kesehatan Republik Indonesia; 2011; p. 7-10.

13. James AG, Solove RJ. The Ohio State University Comprehensive Cancer Center. Wexner Medical Center. Understanding blood tests. February 25, 2013. 